\title{
Clinical research on new drugs (Phase I). Profile of scientific publications: data from the pre-clinical phase and bioethical aspects ${ }^{1}$
}

\author{
Pesquisa clínica com novos fármacos (Fase I). Perfil das publicações científicas: dados da \\ fase pré-clínica e aspectos bioéticos
}

\author{
Vanessa de Souza Brick ${ }^{\mathrm{I}}$, William Saad Hossne ${ }^{\mathrm{II}}$, Rogério Saad Hossne ${ }^{\mathrm{III}}$ \\ ${ }^{\text {I }}$ Master, Sao Camilo University Center, Sao Paulo, Brazil. \\ II Coordinator Postgraduate Program in Bioethics, Sao Camilo University Center and Professor Emeritus, Botucatu School of Medicine, State \\ University of Sao Paulo (UNESP), Botucatu - SP, Brazil. \\ ${ }^{\text {III }} \mathrm{PhD}$, Assistant Professor, Department of Surgery, Botucatu School of Medicine, UNESP), Brazil.
}

\begin{abstract}
Purpose: To trace a profile of scientific publications, phase I, in order to know whether or not they show pre-clinical phase data, emphasizing bioethical aspects. Methods: Sixty-one scientific articles, published in 2007, involving research in human beings using new drugs, medicines and vaccines during phase I were analysed. A schedule for data collection was elaborated in which it would be possible to analyse and evaluate those articles. The schedule included items related to the pre-clinical phase associated to the clinical phase, and items related to the sample characteristics. Results: Most of research works were carried out in USA. Taking into consideration that a large number of works have been dedicated to oncologic affections, most of them were carried out in voluntary ill individuals. Information on the pre-clinical phase, phase I, was very poor or absent. Even though some authors consider the phase I research as a promising one and also suggest some future studies on phase II, the reader is not able to consider the same way, as long as there is a shortage of information on the pre-clinical phase. Conclusion: The profile of scientific publications showed that data deserve some reflections and analysis to better evaluate the publications on phase I.
\end{abstract}

Key words: Biomedical Research. Pharmaceutical Preparations. Scientific and Technical Publications. Bioethics. Ethics, Research.

\section{RESUMO}

Objetivo: Traçar o perfil das publicações científicas de fase I e procurar saber se a publicação oferece dados da fase pré-clínica com ênfase nos aspectos bioéticos. Métodos: Foram analisados 61 artigos científicos publicados no ano de 2007, que relatam pesquisas envolvendo seres humanos com novos fármacos, medicamentos ou vacinas em fase I. Foi elaborado um roteiro para coleta de dados, com o qual fosse possível analisar e avaliar os artigos científicos. O roteiro contempla itens referentes à fase pré-clínica (associados à fase clínica) e itens referentes às características da amostra. Resultados: Nos artigos analisados, a maioria das pesquisas foi realizada nos EUA. Devido ao grande número de publicações destinadas às doenças oncológicas a maioria delas foi realizada com voluntários doentes. Quanto às informações sobre a fase pré-clínica presente nas publicações de fase I observamos que são pobres ou inexistentes. Mesmo que os autores julguem a pesquisa fase I como promissora e sugiram estudos futuros de fase II, ao leitor não é possível este mesmo julgamento pela escassez de informações da fase pré-clínica. Conclusão: O perfil das publicações levanta dados que merecem reflexão e análise para melhor avaliação do que está ocorrendo com as publicações de fase I.

Descritores: Pesquisa Biomédica. Preparações farmacêuticas. Publicações Científicas e Técnicas. Bioética. Ética em Pesquisa.

${ }^{1}$ Work performed at Postgraduate Program in Bioethics, Sao Camilo University Center, Sao Paulo - SP, Brazil.

\section{Introduction}

Scientific experimentation and clinical research have been shown remarkable social benefits, however, from the ethical standpoint the interest of human beings must be beyond science interests. So, there are limitations for clinical research as long as it has to be done according to desirable patterns of ethics and quality, as well as by obeying society believes and values.

The main objective of clinical research must be the protection of the subject ${ }^{1}$ and, furthermore, it is the basis for therapeutic decisions for all physicians and so, is fundamental for these professionals in order to permit them to critically evaluate essays results.

This work examined, for the first time, publications related to new drugs tested in human beings ${ }^{2}$. In the last four decades the principles of experimentation in humans have been defined and established.

According to Resolution no. 251/97 (National Health Council, Ministry of Health), it is a preliminary condition to the drugs test phase, in human beings, be made after an evaluation 
of pharmacokinetic and pharmacodynamic aspects, like toxicity studies, in several animal species and "in vitro". Once these conditions are provided, a clinical research program might be started $^{3}$

Pre-clinical research must generates information which allows a justification for carrying out research works in human beings. Reports on experimental studies must specify the method, toxicological and pharmacokinetic data, cellular models, tissues or animals used, and laboratory tests. Pre-clinical results must show data relevance, possible therapeutic applications and to preview the occurrence of some risks as a consequence of its use.

The toxicological pre-clinical evaluation of a new drug may be divided into 4 stages according to the exposure duration; acute toxicity, dose replications, sub-chronic and chronic condition. If positive, pre-clinical studies will permit the advance to the clinical phase, i.e., human beings taking part of the experiment ${ }^{3}$.

Generally, studies with drugs in humans are conducted in 4 phases. Phase I: a new chemical or biological drug is, for the first time, administered to human beings. Phase II: aims to study the therapeutic efficiency, dose range, kinetics and metabolism. A small number of subjects with a specific affection is selected. Phase III: aims to test the efficiency and safety by using a large number of samples. Phase IV: aims to study the late adverse effects, patterns of drug utilization and additional indications ${ }^{2}$.

Phase I begins with the administration of a small dose of an experimental agent administered to 3 or more subjects. The objective is the establishment of pharmacokinetic parameters, single and/or multiple dose and, specially, the absolute bioavailability of the pharmaceutical form, in order to establish the dose and posologic regimen. Simultaneously, an evaluation of the substance safety is made.

So, as above reported, the relevance of the clinical research, phase I, becomes evident for it deals with the first application in humans and the results will permit the advance of the research in other human beings ${ }^{4}$. Obviously, the scientific rigor must orient all the research phases. It is essential for phase I and so the scientific community will necessarily have access to a honest, complete and large spectrum of pertinent information.

Nowadays many experiments that involved human beings in the past under some conditions are considered ethically incompatible. People rights have to be protected for, as shown by history, an individual wherever he is, with no conditions to react, be by ignorance, mental incapacity or imprisonment, there will be the possibility for a researcher to conduct an experiment guided by his own consciousness ${ }^{1}$.

To avoid an ethical misleading and guarantee safety, it was necessary a discussion and documents preparation like policies and ethical norms ${ }^{5,6,7}$. Also, over the years technicalscientific requirements have been established by regulatory agencies and sanitary vigilance organisms, e.g., Food and Drugs Administration (FDA), European Medicines Agency (EMEA) and Sanitary Vigilance National Agency (ANVISA) ${ }^{3,8,9,10,11}$ in order to guide clinical research in humans.

Taking national and international ethical policies and regulatory norms as references, the work aimed to trace the profile of scientific publications phase I emphasizing the bioethical aspects. The following answers were searched for: 1) Is there any published technical-scientific information taking into consideration regulatory norms on the pre-clinical phase? 2) Are relevant data established in the ethical norms available to the reader? 3) In negative case, which items and respective frequencies are not reported? 4) Last but not least, do published data allow the scientific community a correct analysis from the bioethical point of view?

\section{Methods}

Scientific articles published in 2007 (January to October) involving new drugs in human beings, medicines or vaccines, phase I, were analysed. References were obtained from database "on line" Scopus (www.scopus.com) at the Library of the Faculty of Medicine, UNESP, Botucatu - SP. This database totalized 15, 000 journals from more than 4,000 presses, 33 million records, from which 16 million references from 1996 on.

Search was based upon the word "phase I", in the title, and strictly for the year 2007. Articles related to drugs combination were excluded for most of them were related to drugs previously tested and approved for the next phases (II, III and IV). Therefore, drugs combination were considered inappropriate for the objective of the work, as well as literature review, editorials, and experiences reports.

Based on statements, norms and ethical policies, and regulatory resolutions, a list of questions was developed for data collection, with which it would be possible the analysis of the scientific articles (clinical research phase I) according to the purpose of this work. The list of questions provided items related to the pre-clinical phase (associated to clinical phase), and items related to sample characteristics. Technical-scientific articles were also included taking into consideration the focus on bioethics, in which norms and ethical policies are a part, besides the regulatory agencies requirements.

\section{Results}

Sixty-one scientific articles published in international journals in 2007 were analysed. Most of the authors were within the range of 7 to 11 for most of the articles (59\%). Articles by 5 $(6.5 \%)$ and $30(1.6 \%)$ authors were found. The participation of many authors was linked to multi-focused research. No Brazilian as a main author was found. The pharmaceutical world industry consists of more than 10, 000 companies.

The distribution of articles according to the main author and country is in Table 1.

TABLE 1 - Distribution of articles according to the main author and country

\begin{tabular}{lll}
\hline \multicolumn{1}{c}{ Country } & $\mathrm{f}$ & $\mathrm{p}$ \\
\hline \hline USA & 27 & 44.3 \\
\hline United Kingdom & 5 & 8.2 \\
\hline Germany & 4 & 6.6 \\
France & 4 & 6.6 \\
\hline Australia & 3 & 4.9 \\
Netherlands & 3 & 4.9 \\
Japan & 3 & 4.9 \\
\hline Others & 12 & 19.7 \\
\hline
\end{tabular}

$\mathrm{f}=$ frequency, absolute numbers

$\mathrm{p}=$ relative frequency, $\%$ 
The presence of sponsors was examined only as a way to characterize the sample, with no direct relation with ethics in the development of the clinical research. The presence of sponsors including pharmaceutical industries, government institutions, schools and even veterinary hospitals was recorded in $64 \%$ of the cases.

Figure 1 shows the great concentration of clinical research phase I in oncologic diseases.

\section{Distribution according to disease}

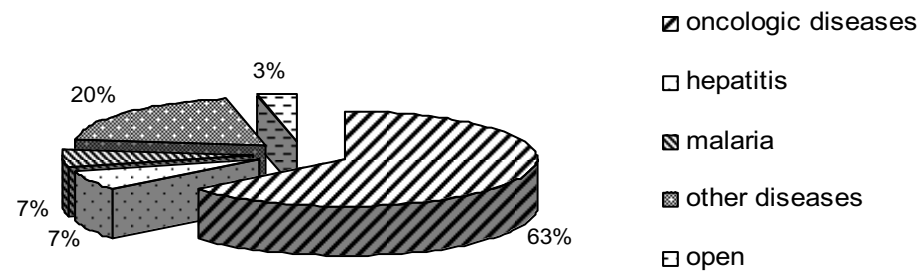

FIGURE 1 - Articles frequency distribution according to disease

From the bioethical standpoint, researches dealing with oncologic diseases deserve some considerations. Several publications pointed out research works carried out in patients bearing an advanced oncologic condition or even experiencing a terminal status. So it seems essential to submit all data and their analysis of risks $\mathrm{X}$ benefits in order to assess whether the subject of search is not being used only as biological preparation. In our view, the bioethics assessment should take into account mainly the reference of non malefficiency.

Technical Regulation on Clinical Research Good Practices Verification (MERCOSUL/GMC Resolution no. 129/96) says: "The clinical research should be preceded by pre-clinical studies and can be the start searches in Clinical Pharmacology at the time that the results of such studies allow infer that the risks to the health of the people involved are not significant and predictable".

Table 2 shows the presence of citation or reference of the pre-clinical in the text.

TABLE 2 - Pre-clinical phase reference in the article

\begin{tabular}{|c|c|c|c|c|c|c|}
\hline & $\operatorname{sim}$ & & não & & & \\
\hline & $f$ & $p$ & $f$ & $p$ & \multirow{2}{*}{\multicolumn{2}{|c|}{ Not published }} \\
\hline Text fase description & 36 & 59 & 25 & 41 & & \\
\hline $\begin{array}{l}\text { Sufficiency of data for } \\
\text { evaluation }\end{array}$ & 13 & 21.3 & 48 & 78.7 & f & $p$ \\
\hline References citation & 44 & 72.1 & 15 & 24.6 & 2 & 3.3 \\
\hline
\end{tabular}

$\mathrm{f}=$ frequency, absolute numbers

$\mathrm{p}=$ relative frequency, $\%$

Considering that, for the first time, such a drug has been used in humans, it seems of extreme importance a good description of the pre-clinical phase. However, there was no description in almost $41 \%$ of the cases, even in the references $(25 \%)$. Furthermore, in about $80 \%$ of the articles no sufficient data are shown in order to permit understanding the previous phase.

In the pre-clinical phase, no article reported the number or sex of animals. Animal species are described in Table 3.
TABLE 3 - Animal species

\begin{tabular}{lll}
\hline Animal & $\mathrm{f}$ & $\mathrm{p}$ \\
\hline \hline Not cited & 29 & 47.5 \\
Rats & 7 & 11.5 \\
Mice & 6 & 9.8 \\
Mice and rats & 3 & 4.9 \\
Rats and monkeys & 3 & 4.9 \\
Dogs and rats & 3 & 4.9 \\
Monkeys & 2 & 3.3 \\
Association animals and other animals & 8 & 13.1 \\
\hline
\end{tabular}

$\mathrm{f}=$ frequency, absolute numbers

$\mathrm{p}=$ relative frequency, $\%$

As for animal species used in the pre-clinical phase, only 14 articles $(22.9 \%)$ included a non-rodent mammal.

Table 4 shows that in almost $60 \%$ of the sample it was not possible to evaluate the way the pre-clinical phase study was carried out as long as there is no description whether or not animals were healthy or sick. In case of sick animals, no model is ascribed in the articles (about 10\%).

TABLE 4 - Animal characteristics

\begin{tabular}{llc}
\hline & $\mathrm{f}$ & $\mathrm{p}$ \\
\hline \hline Not cited & 36 & 59 \\
Bearing disease & 21 & 34.4 \\
Healthy & 4 & 6.6 \\
\hline $\mathrm{f}=$ frequency, absolute numbers & & \\
$\mathrm{p}=$ relative frequency, $\%$ & &
\end{tabular}

Table 5 shows text citations on the pre-clinical phase pharmacodynamic analysis, safety information, efficiency and dose for pre-clinical phase. However, a little more than half the articles did not cite that analysis.

TABLE 5 - Articles distribution pharmacodynamic analysis

\begin{tabular}{lcc}
\hline & $f$ & $p$ \\
\hline \hline Yes & 32 & 52.5 \\
No & 29 & 47.5 \\
\hline f $=$ frequency, absolute numbers \\
$\mathrm{p}=$ relative frequency, $\%$
\end{tabular}

Details related to the study of acute toxicity were found in 23 articles, $37.7 \%$ (Table 6).

TABLE 6 - Articles distribution related to references on acute toxicity studies

\begin{tabular}{lcc}
\hline & $f$ & $p$ \\
\hline \hline Yes & 23 & 37.7 \\
No & 38 & 62.3 \\
\hline
\end{tabular}

$\mathrm{f}=$ frequency, absolute numbers $\mathrm{p}=$ relative frequency, $\%$ 
Only some articles (24.6\%) reported the same via employed in the clinical phase and one of them used a different via, what seems impracticable.

The administration via for the study of acute toxicity was as follows: oral $(9.8 \%)$, subcutaneous and intravenous injection, $6.6 \%$ and $3.3 \%$, respectively, subcutaneous implant $(1.6 \%)$, nasal $(1.6 \%)$, oral-intravenous combination $(1.6 \%)$ and no cited via $(13 \%)$.

However, approximately $63 \%$ of the articles dealt with data on acute toxicity, and some did not cite the administration via; consequently the reader has no way to know it, in the pre-clinical phase or even, whether or not it was the same via for phase I.

Sub-acute toxicity studies appeared in only 3 articles $(4.9 \%)$ and only one cited the administration via. Likewise, just one article dealt with the fertility effect (1.6\%).

The duration of the experiment for the pre-clinical phase was reported in only 3 articles. The Technical Regulation on the Verification of Good Practices in Clinical Research (MERCOSUL/GMC Resolution no. 129/86) recommends a period of time of 12 to 24 weeks, according to the characteristics of the product, proposed therapeutics application and animal species.

\section{Discussion}

The biggest pharmaceutical transnational export companies are located in Switzerland, Germany, United Kingdom and Sweden. Countries like Belgium, Denmark and Ireland also present superavits in their commercial balances. On the other hand, countries of East Europe, South Korea, Australia. Italy, Finland, Norway and Japan import substantial raw materials and pharmaceutical products. The USA is the biggest producer and simultaneously the biggest consumer of medicines in the world ${ }^{8}$.

According to the "Basic Principles for Clinical Research, item 2, Helsinki Declaration, 2000": “Clinical Research involving human beings must be in conformity with the scientific principles generally accepted and be based upon the detailed knowledge of the scientific literature, other relevant information sources and laboratory experimentation, and in animal experimentation when appropriate" (same as in Resolution no. 251/97 CNS/MS, item IV.1, "e").

Brazilian Resolution no. 251/97 CNS/MS states: "toxicity studies must be carried out at least in 3 animal species of both sexes including one non-rodent mammal." Also, other Brazilian resolutions state that clinical research has to be justified based on results obtained in the pre-clinical phase:

"Pre-clinical detailed information necessary to justify the projects phase, including a report of experimental studies (material and methods, animals used, laboratory tests, pharmacodynamic data, safety limits and toxicology as for drugs, medicines and vaccines). Pre-clinical results must be shown along with a discussion on data relevance in connection with expected therapeutic and possible undesirable effects in humans."

Toxicity studies are oriented by technical norms as described in the Technical Regulation on Pre-Clinical Good Practices (MERCOSUL/GMC Resolution no. 129/96):
"Acute toxicity: studies must be carried out at least in 3 species including a non-rodent one. At least 2 administration via must be used, one related to that recommended for the proposed therapeutic use and the other assuring the drug absorption."

According to Brazilian Resolution no. 251/97 CNS/MS states (item IV.1, “f”, “g”):

"... in the study of sub -acute and chronic toxicity with repeated doses, the administration via must be related to the therapeutic application proposal: duration of the experiment must be 24 weeks at least."

Studies on acute and sub-acute toxicity are oriented by technical norms such as the Technical Regulation on Clinical Research Good Practices Verification (MERCOSUL/GMC Resolution no. 129/96):

"Sub-acute toxicity with repeated doses. Must be carried out in at least 2 species including a non-rodent one."

And by ethical resolutions Resolution no. 251/97 CNS/MS:

"Pre-clinical toxicology data are related to the study of acute, subacute and chronic toxicity with repeated doses."

In disagreement with Resolution no. 251/97 CNS/MS, no article on the effect on embryotoxicity, mutagenic activity and oncogenic potential was cited in opposition to other norms on clinical research:

"In the pre-clinical phase, toxicity studies must also include the effects on fertility, embryotoxicity, mutagenic activity, oncogenic potential (carcinogenic) and other studies according to drugs characteristics and therapeutic proposal."

Data omission as for pre-clinical phase in article on phase I is probably due to journals space limitations or need to emphasize results in the current phase.

No citation of these data on the pre-clinical phase, phase $\mathrm{I}$, is probably due to the limitation of space in the journals and, also, to emphasize results from the current phase. So, the reader has to conclude by his own and to believe the pre-clinical research was within the international patterns requirements ${ }^{12}$.

In a previous work on the bioethical analysis of pre-clinical research, phase III, it was concluded that as for the pre-clinical phase there is a lack of information related to the animal species used as for toxicity tests and the pathology experimental models or "normal" animals"13.

Researches on bioethical analysis have been a fundamental contribution for the advancement of scientific works in human beings and for the Research Ethical Committees (REC) as for future clinical phase I research reviews. 


\section{Conclusion}

Publications profile arise questions that deserve some reflections and analyses for a better evaluation on what is occurring in the publications phase I, including suggestions as for future studies about the combination between the variables described.

Even though the reported documents make rules mandatory, this work showed that not all publications contain technical-scientific information or relevant data in agreement with regulatory norms.

The scientific community expects that data not presented, as for pre-clinical as well as clinical phase I be, at least, submitted to or an Ethical Committee.

\section{References}

1. Vieira S, Hossne WS. Pesquisa médica: a ética e a metodologia. São Paulo: Pioneira; 1998.

2. Hardman JG, Limbird LE, Gilman AG. Goodman \& Gilman: as bases farmacológicas da terapêutica. Rio de Janeiro: Mcgraw-Hill; 2003.

3. Brasil. Ministério da Saúde. Conselho Nacional de Saúde. Resolução 251/ 97. Disponível em http://conselho.saude.gov.br [Acesso em: 19 set. 2007]. 4. Mercosul. Regulamento técnico sobre a verificação de boas práticas de pesquisa clínica: Mercosul/GMC/Res. No 129/96. Disponível em www.mercosulsalud.org [Acesso em: 29 set. 2007].
5. CIOMS. International ethical guidelines for biomedical research involving human subjects. Geneva: Council for International Organizations of Medical Sciences, WHO; 2002.

6. CREMESP. Conselho Regional de Medicina do Estado de São Paulo. Código de Nuremberg. Trials of war criminal before the Nuremberg Military Tribunals. 1947. Disponível em www.bioetica.org.br [Acesso em: 29 set. 2007].

7. CREMESP. Conselho Regional de Medicina do Estado de São Paulo. Declaração de Helsinque: outubro/2000. Disponível em www.bioetica.org.br [Acesso em: 29 set. 2007].

8. Brasil. Agência Nacional de Vigilância Sanitária. Bioética e Vigilância Sanitária. Brasília: Anvisa; 2007.

9. Brasil. Ministério da Saúde. Conselho Nacional de Saúde. Resolução 196/96. Disponível em http://conselho.saude.gov.br [Acesso em: 19 set. 2007].

10. Directive 2001/20/EC of the EU Parliament and of the Council of 4 April 2001. Official Journal of the European Communities 2001. Article 1 Scope $\S$ 2, 1.5.2001: L 121/34. Disponível em http://emea.europa.eu [Acesso em: 29 set. 2007].

11. US FDA. Federal Food, Drug, and Cosmetic Act. As amended through December 31, 2004. Disponível em http://fda.com

12. Angell M. A verdade sobre os laboratórios farmacêuticos: como somos enganados e o que podemos fazer a respeito. Rio de Janeiro: Record; 2007.

13. Miranda EB. Perfil das publicações científicas (ano 2005) referentes às pesquisas clínicas (Fase III) à luz da bioética [Mestrado]. São Paulo: Centro Universitário São Camilo; 2007.

Conflict of interest: none

Financial source: none

\section{Correspondence:}

Vanessa de Souza Brick

Rua Carlos Guadagnini, 1988

18610-120 Botucatu - SP Brazil

vanessabrick@hotmail.com

Received: June, 25, 2008

Review: August 20, 2008

Accepted: September 23, 2008

\section{How cite this article}

Brick VS, Hossne WS, Hossne RS. Clinical research on new drugs (Phase I). Profile of scientific publications: data from the pre-clinical phase and bioethical aspects. Acta Cir Bras. [serial on the Internet] 2008 Nov-Dec;23(6). Available from URL: http://www.scielo.br/acb 